\title{
Dynamic of Accumulation of Dry Substance and Formation of Photosynthetic Surface of Pea According to the Fattening Food Dose
}

\author{
Alaric Makoundou ${ }^{1 *}$, Ilitch Christian Nguinda -Akani², Joseph Yoka ${ }^{3}$ \\ ${ }^{1}$ Laboratory of Physiology and Plants Production, Faculty of Sciences and Technicals \\ ${ }^{2}$ Biodiversity and Phytotechnical Laboratory, Superior National School of Agronomy and Forestry \\ Marien Ngouabi University, Congo \\ ${ }^{3}$ Botanical and Ecology laboratory, Faculty of Sciences and Technicals \\ Marien Ngouabi University, Congo \\ *Corresponding author's email : alaricmak [AT] gmail.com
}

\begin{abstract}
The objective of study is to appreciate the influence of different manure of dynamic accumulation of dry substances on the local variety of pea. It has been establish a considerable influence of manure on the photosynthetic potential of plants and photosynthesis production of pea (Pisum Sativum LS).

Methodology and results : four dose, only or combined, Nitrogen, phosphorus, and Potassuim have been brought on the variety plantation local of pea. Organic manure were brought under form of rot manure. The dynamic of increasement daily means of dry substance at plantation air during vegetation of pea presented an interest. The resultats show that the combined contribution $\left(N_{25} P_{30} K_{30}\right)$ has increased the production of local variety pea. The analyse of photosynthetic potential of plants of all period of germination to the formation of bud show that, this indication is more arise in the variants with the average dose of NPK and with the use of residual effects of organomineral system of $1677,2 \mathrm{~m}^{2} /$ ha the day to $1685.1 \mathrm{~m}^{2} / \mathrm{ha}$ the day. The biggest mass of dry substance of pea plantation is formed during the period full maturity, which is formed in functionof manure dose studied $\left(400,0-576,9 \mathrm{~g} / \mathrm{m}^{2}\right)$.

Conclusion: the manure influence positively the increasement of accumulation of the dry substance by the pea plantation. This work illustrate the effect of photosynthetic variations in period of interphase of grains maturity dependent of mineral nutrition and climatics conditions.
\end{abstract}

Keyswords---: dynamic, accumulation, pea, manure

\section{INTRODUCTION}

The new varieties local of pea with a kind different leaves and others well caracteristics economically advantageous have a parspective to obtain the great harvest of pea grains. By elsewhere, it apperead necessary to establish reaction of these varieties on different agricultural technical. The pea is one of principal leguminuous plant produce which present a source of plant proteins and contribut to the feeding security inorder to reply to the request and the reduction of the poverty. Supplying question in proteines much animals that plants is one of major preoccupation which touch the most poor countries Singh, 1992. It is also important to mark that the pea is adapt well to the abioriques constraint (dryness, inadequacy in phosphorus and Nitrogen, acidity of grounde) and biotiques (sickness and enemy)

( Bressani, 1997), reason why itis an available cultivation during all year, when the other become sparse the pea contribut to the restauration or to the maintenance of grounds fertility (Borget, 1989). Beyond it can serves plant covering and green manure for the protection of grounds against hydric wearing (Tothill, 1986). The most great of cultivated surfaces is found in wertern Africa (Quin, 1997) and cover with 80\% central Africa cultivated surfaces (Abdou, 1997). In Congo,that plant specy is more and more appreciate by the Congolese which become consummer of these grains ; however his cultivation rest gain marginal. In agricultural politic plan, only peanut vulgar beans and the soja represent in the national program of agricultural development (Anonyme, 2008). The pea is not cultinate in the traditional agricultural system that for help to diversify family feedind (Kinzila, 2009).

The program of our experiences gets in the center on agricultural technics vulgarization (CVTA) in 2016-2018, forecast the study of the pea reaction on different feeding seat.

The general objectif of this study is to determinate the dynamic of accumulation of dry substances in function of different fertilizer.

The specifics objectives are :

$\checkmark$ Determinate the period of fertilizer contribution

$\checkmark$ Estimate the dynamic of accumulation of dry substances on pea production 
$\checkmark$ Determinate photosynthetic surface according to the manure dose.

\subsection{Agricultural material}

\section{MATERIAL AND METHODS}

The plant material consisted of pea seeds of "local" variety. The variety used in this study came from the National Institute for Agronomic Research (IRA), located in the southern zone of the country, in the department of Bouenza. This variety is also distinguished from other varieties by a higher protein content.

\subsection{Experimental site}

Experimentation is bring to in 2016-2018 in center agricultural technical of vulgarization situated to 17 Kilomter in the sauth of Brazzaville the center is submissive to a wet tropical type of climate bas congolais, caracterise by two great seasons distinct, to Know :- a rain season goes to october at may with abundant rains occasional by a dry season to january at february ; a great dry season to june at september ( Anonyme 1989) the middle pluviometrie is to order of 1200 to $1400 \mathrm{~mm}$ water by year unequally retort. The vegetation is formed by a savannah composed of : a herbaceous stratum to Hyparrhenia diplandra (Hack) staff; plants stratum based on acidophile trees of species Hymenocardia acida Tull Anonyme, 1989) trees fruits as the mangoes trees, oranges trees ...,the lands of agricultural technical vulgarization have a prediminance sandy argilo with $\mathrm{Ph}$ variant between 4 and 5,5. These grounds are chemically poor, inadequacy calcuim. The sum of exchangeable base in feferior at $1 \mathrm{mg}$ (Anonyme, 1989).

\subsection{Methods}

Experience has been intrigue in stationary rotation of cultivation grains. The structure of cultivate lands in rotation is the belong :- $50 \%$ of cereal, $40 \%$ of plowing, $10 \%$ of beans. The pea was sow of simply way with space between two tines of $15 \mathrm{~cm}$ and the density to hectare has beens of 1,2 millions plantation. During all the years of research, they are the variety (Local) of maize procursor of pea. Total surface is of $190,4 \mathrm{~m}^{2}\left(5,6 \mathrm{~m} \mathrm{x} \mathrm{34.0m)} \mathrm{the} \mathrm{size} \mathrm{used} 108 \mathrm{~m}^{2}(3,6 \mathrm{~m} \times 30,0 \mathrm{~m})\right.$. The repetition of experience is four time ; the investment of the cup is systematic. In our research the indicator of leaves surface (ISF) or, otherwise, the dimension of leaves surface which comeback to the unity of sowing surface, to reckoning that many leaves of a tree, that the density during considered period of development was measured during pea vegetation. It brought mineral manure by prevailed dose according. The plan of experience for general treatment of ground. The following manure have been brought ; Nitrogen manure : ammonioacal sulphate (34\% Nitrogen) granule superphosphate phosphorique $\left(19,4 \% \mathrm{P}_{2} \mathrm{O}_{5}\right)$

and potassiques manures : potassium choride $\left(42 \% \mathrm{~K}_{2} \mathrm{O}\right)$. organic manure were brought under the form of semi manure rot with a norm of $60 \mathrm{t} / \mathrm{ha}$ under the preceding effect.

The prevailed dose according of experience plan for the general treatment of ground :

1. Roll-without manure ;

2. Minimal dose of complete mineral manure $\left(\mathrm{N}_{12,5} \mathrm{P}_{15} \mathrm{~K}_{30}\right)$;

3. Middle dose of complete mineral manure $\left(\mathrm{N}_{25} \mathrm{P}_{30} \mathrm{~K}_{30}\right)$;

4. Organo- mineral manure system (consequency NKP, of manure and the traw) ;

5. Terfilizationof pea in germination phase to the dose $\mathrm{N}_{23}$.

The experimental purview is a fisher block of four (4) repetitions. Each block is subdivided into five (5) plots correspond at five treatment which :

To (roll); $\mathrm{T}_{1}\left(\mathrm{~N}_{12,5} \mathrm{P}_{15} \mathrm{~K}_{15}\right) ; \mathrm{T}_{2}\left(\mathrm{~N}_{25} \mathrm{P}_{30} \mathrm{~K}_{30}\right)$; $\mathrm{T}_{3}$ (residual effect $\mathrm{NPK}$; manure) ; $\mathrm{T}_{4}\left(\mathrm{~N}_{25}\right.$ fertilization).

\begin{tabular}{|l|l|l|l|l|l|}
\hline $\mathbf{T}_{4}$ & $\mathbf{T}_{1}$ & $\mathbf{T}_{\mathbf{0}}$ & $\mathbf{T}_{\mathbf{3}}$ & $\mathbf{T}_{\mathbf{2}}$ & Blok1 \\
\hline
\end{tabular}

\begin{tabular}{|l|l|l|l|l|}
\hline $\mathbf{T}_{1}$ & $\mathbf{T}_{\mathbf{3}}$ & $\mathbf{T}_{\mathbf{4}}$ & $\mathbf{T}_{\mathbf{2}}$ & $\mathbf{T}_{\mathbf{0}}$ \\
\hline
\end{tabular}

\begin{tabular}{|l|l|l|l|l|l|}
\hline $\mathbf{T}_{\mathbf{0}}$ & $\mathbf{T}_{\mathbf{2}}$ & $\mathbf{T}_{\mathbf{3}}$ & $\mathbf{T}_{\mathbf{1}}$ & $\mathbf{T}_{\mathbf{4}}$ & Blok 3 \\
\hline
\end{tabular}

\begin{tabular}{|l|l|l|l|l|}
\hline$T_{2}$ & $\mathbf{T}_{3}$ & $\mathbf{T}_{\mathbf{0}}$ & $\mathbf{T}_{\mathbf{4}}$ & $\mathbf{T}_{\mathbf{1}}$ \\
\hline
\end{tabular}

Figure1 : schedule of experimental purview.

\section{RESULTS AND DISCUSSION}

\subsection{Results}

The greater of accumulation of dry material is an indicator of vegetation condition and the formation of harvest. The dimension of trees and treir accumulation of dry material determinate many cereal harvest (Baldy, 1993). In our research, 
the dynamic of this indicator on unity of sowed surface is determinate differently. The dose of manure used increase this indicator by the variant no fertilised at $20,2-29,2 \%$ in the germination phase $13,8-26,5 \%$ in the flowering phase, $17,2-$ $27,8 \%$ in the phase of formation bud and to $20,3-30,7 \%$ in the phase of plenty grains maturity to reckoning of this indicator to the roll 6,$8 ; 63,9 ; 187,0 ; 400,0 \mathrm{~g} / \mathrm{m}^{2}$ (Table1).

Table 1: dynamic of accumulation of dry substance by the pea plants according to the manure dose, $\left(\mathrm{g} / \mathrm{m}^{2}\right) ; 2016-2018$.

\begin{tabular}{|c|c|c|c|c|c|c|c|}
\hline \multirow[b]{2}{*}{$\begin{array}{l}\text { Variant of } \\
\text { experience }\end{array}$} & \multicolumn{4}{|c|}{ Cultivation Phase } & \multirow{2}{*}{$\begin{array}{l}\text { Middle daily } \\
\text { increase of dry } \\
\text { substance for } \\
\text { germination } \\
\text { period of full } \\
\text { maturity }\end{array}$} & \multirow{2}{*}{$\begin{array}{l}\text { Middle daily } \\
\text { increase of day } \\
\text { substance for } \\
\text { the period of } \\
\text { formation of } \\
\text { bud full } \\
\text { maturity }\end{array}$} & \multirow{2}{*}{$\begin{array}{l}\text { Middle daily } \\
\text { increase of dry } \\
\text { substance for } \\
\text { the germination } \\
\text { period } \\
\text { formation of } \\
\text { buds. }\end{array}$} \\
\hline & $\begin{array}{l}\text { Germ } \\
\text { inatio } \\
n\end{array}$ & Flowering & $\begin{array}{l}\text { Buds } \\
\text { forma } \\
\text { tion }\end{array}$ & $\begin{array}{l}\text { full } \\
\text { maturity }\end{array}$ & & & \\
\hline 1.Roll & 6,8 & 63,9 & 187,0 & 400,0 & 4,64 & 7,42 & 3,85 \\
\hline 2. $\mathrm{N}_{12,5} \mathrm{P}_{15} \mathrm{~K}_{15}$ & 8,5 & 74,1 & 225,9 & 501,9 & 5,83 & 9,62 & 4,66 \\
\hline 3. $\mathrm{N}_{25} \mathrm{P}_{30} \mathrm{~K}_{30}$ & 9,6 & 85,6 & 258,9 & 576,9 & 6,70 & 11,08 & 5,34 \\
\hline $\begin{array}{l}\text { 4. residual } \\
\text { effect NPK, } \\
\text { manure }\end{array}$ & 9,1 & 86,9 & 259,2 & 569,7 & 6,62 & 10,82 & 5,36 \\
\hline $\begin{array}{l}5 . \mathrm{N}_{25} \\
\text { fertilization }\end{array}$ & 8,7 & $\mathbf{7 7 , 7}$ & 236,8 & 507,3 & 5,89 & 9,43 & 4,89 \\
\hline
\end{tabular}

The result of this table reveal that the greatest mass of dry material of plant of pea is formed during the period of full maturity, in function of studied dose of manure $\left(400,0-576,9 \mathrm{~g} / \mathrm{m}^{2}\right)$.

Middle daily increase of dry material in air of plants during the pea cultivation present an interest, in the fact that they think, the dry material of stalks is formed before the flowering and in the reproduction period ( grace to the accumulation of dry material in the generating organ).

In our researches, middle daily increase of dry substance to the beginning of the cultivation (germination- bud formation) if of $3,85 \mathrm{~g} / \mathrm{m}^{2}$ by day, in function of manure dose. Middle daily increase of dry substance of 17,4 to $28,2 \%$ attain the maximal value in the variants with the middle dose of NPK and the bottom of mineral organic system of $5,34 \mathrm{~g} / \mathrm{m}^{2} \mathrm{by} \mathrm{day}$, it was been increased of $48,1-51,8 \%$; that it testify an intensive growth of dry substance during that period. Many grace to the vegetative organs that generating (beans). The presentation of minerals manure has favoured increasement of this indicator of 21,3 to $33,0 \%$. The mathematic treatment of received data testify the existence of an close bond between the accumulation of dry substance during the phase of complet maturity and the fertility of pea grains $(r=0,839 \pm 0,172)$. The manure strengthen considerably synthetic action of plans, influence the growth and the continue of functioning of assimilation machinery and, finally reckoning, the harvesting (Nitchiporovich 1973). In means during three years of maximal brought, the indicator of leaves surface is perceptible in the appearance phase of buds and present like this :2,66$3,73 \mathrm{~m}^{2} / \mathrm{m}^{2}$.

Table 2 : Dynamic of formation of pea leaves of surface in function of manure dose, $\left(\mathrm{m}^{2} / \mathrm{m}^{2}\right), 2016-2018$.

\begin{tabular}{|l|c|c|c|c|}
\hline \multirow{2}{*}{ Variant experience } & \multicolumn{4}{c|}{ Cultivation phase } \\
\cline { 2 - 5 } & Germination & Flowering & $\begin{array}{c}\text { Formation of } \\
\text { buds }\end{array}$ & Complet maturity \\
\hline 1. Roll & 0,151 & 1,16 & 2,66 & 2,01 \\
\hline 2. $\mathrm{N}_{12,5} \mathrm{P}_{15} \mathrm{~K}_{15}$ & 0,187 & 1,34 & 3,22 & 2,47 \\
\hline 3. $\mathrm{N}_{25} \mathrm{P}_{30} \mathrm{~K}_{30}$ & 0,212 & 1,57 & 3,68 & 2,82 \\
\hline 4. residual effect NPK manure & 0,200 & 1,58 & 3,73 & 2,82 \\
\hline 5.N $\mathrm{N}_{25}$ fertilization & 0,189 & 1,41 & 3,41 & 2,61 \\
\hline
\end{tabular}


In table 2 : germination to the phase of buds formation, there is an increasement plants leaves of the surface, which, to the complet maturity the grains succeed the purview disappearance of leaves. There by, the germination at the flowering, in middle, in three years, index of the leaves surface is become greater of 616 to $690,0 \%$ to the flowering phase at bud formation (of 129,3 to 141,8\%). Therefore, there is the reduction of index of leaves surface (ISF) according the employment dose of manure (23,3-24,4\%). The changing of the index of leaves surface (ISF) by return of studied doses of manures and to the cultivation condition has been (meticulousty observed in middle during three years. In each separatily hold, with the increase of manures doses or during the use of residuals effects of organo- mineral system there is an increase of ISF in comparison with the no fertilized variant : during presentation the minimal dose of $\left(\mathrm{N}_{12,5} \mathrm{P}_{15} \mathrm{~K}_{15}\right)(13,4-19,3 \%)$; the middle dose $\left(\mathrm{N}_{25} \mathrm{P}_{30} \mathrm{~K}_{30}\right)(26,1-28,8 \%)$; of the use of residual effect of organa- mineral system (25,0-28,7\%) and during the presentation of middle dose of Nitrogen in the fertilization $(17,7-22,0 \%)$. The rceation of seed with anoptimal surface of leaves, which are capable to stay in a regular state during a long time ( provide assimilants to the reproductives organs and the plants stocking); the indicator which unit the surface of leaves plants and the time of work of leaves is the photosynthetic potential seed (pps).

In middle, during the research years, the most lower photosynthetic potential of seed has been observed during the germination period until the flowering in his variant with the use of manure dose of manure : $170,5 \mathrm{~m}^{2} / \mathrm{ha}$ in the day; the use of minimal dose of manure $\left(\mathrm{N}_{10,5} \mathrm{P}_{15} \mathrm{~K}_{30}\right)$ has favour the increase of this indicator to the higher 13,6\% (table 3).

Table 3 : the potential photosynthetic pea of seed by return to the manure dose ( $\mathrm{m}^{2} /$ ha by day).

\begin{tabular}{|c|c|c|c|c|}
\hline \multirow[b]{2}{*}{ Variant experience } & \multicolumn{4}{|c|}{ Cultivation phase } \\
\hline & Germination & Flowering & $\begin{array}{c}\text { Formation of } \\
\text { bud }\end{array}$ & $\begin{array}{l}\text { During the } \\
\text { period of } \\
\text { germination } \\
\text { formation of } \\
\text { buds. }\end{array}$ \\
\hline 1.Roll & 170,5 & 424,4 & 618,5 & 1213,4 \\
\hline 2. $\mathrm{N}_{12,5} \mathrm{P}_{15} \mathrm{~K}_{15}$ & 197,4 & 509,4 & 754,3 & 1461,1 \\
\hline 3. $\mathrm{N}_{25} \mathrm{P}_{30} \mathrm{~K}_{30}$ & 232,1 & 595,0 & 850,1 & 1677,2 \\
\hline 4. Residual effect NPK, manure & 229,8 & 603,9 & 851,4 & 1685,1 \\
\hline 5. $\mathrm{N}_{25}$ fertilization & 206,0 & 541,1 & 792,7 & 1539,4 \\
\hline
\end{tabular}

The doubly of dose of mineral manure $\left(\mathrm{N}_{25} \mathrm{P}_{30} \mathrm{~K}_{30}\right.$ ) has arise the pps to $16,5 \%$ and the use of residual effects of organomineral system at $25,8 \%$. The fertilization by Nitrogen to a middle dose $\left(\mathrm{N}_{25}\right)$ is effective at $17,2 \%$. In the interfacial period ( flowering appearance of bud) it has been remark an analogous regularity : in the turn variant this indicator increase of 16,7 to $29,7 \%$. forming 509,4 to $603,9 \mathrm{~m}^{2} /$ ha by day, with a value in roll variant of $424,4 \mathrm{~m}^{2} / \mathrm{ha}$ by day.

The resultats show that the greatest photosynthetic potential of seed of pea is constituate during the formation of bud phase. In the variant where the manure are not employe, this indicator is of $618,5 \mathrm{~m}^{2} / \mathrm{ha}$ the day. And in the return variant of 754,3 to $851,4 \mathrm{~m}^{2} /$ ha the day. It means that the indicator of that caracteristic is increased of 18,0 to $27,4 \%$. The analyse of photosynthetic potential of seed of all period of germination to the formation of bud shiw that this indicator is more arise in the variants with a middle dose of NPK and with the use of residuals effects of organo-mineral system of $1677,2 \mathrm{~m}^{2} / \mathrm{ha}$ the day to $1685,1 \mathrm{~m}^{2} /$ ha the day ,then in the variant of roll this indicator is of $1213,4 \mathrm{~m}^{2} /$ the day. The introduction of the minimal manure $\left(\mathrm{N}_{12,5} \mathrm{P}_{15} \mathrm{~K}_{15}\right)$, but equally the introduction of Nitrogen of minure $\left(\mathrm{N}_{25}\right)$ has increase the photosynthetic potential of seed to $16,9 \%$ and $21,2 \%$. The analyse of the productuvity of unity of the surface leaves in unity of time has showed, that in middle of three years this indicator during the interfacials periods has change in the dimensions of 3,24 to $3,64 \mathrm{~g} / \mathrm{m}^{2}$ of leave the day (table 4$)$. 
Table 4 : dynamic of clean profitebility of photosynthetic pea by return to the manure dose $\left(\mathrm{g} / \mathrm{m}^{2}\right.$ the day); in middle 2016-2018.

\begin{tabular}{|c|c|c|c|c|}
\hline \multirow[b]{2}{*}{ Variant of experience } & \multicolumn{4}{|c|}{ Cultivation phase } \\
\hline & Germination & Flowering & $\begin{array}{c}\text { Formation of } \\
\text { bud }\end{array}$ & $\begin{array}{l}\text { During the } \\
\text { period of } \\
\text { germination- } \\
\text { formation of } \\
\text { bud }\end{array}$ \\
\hline 1.Roll & 3,49 & 3,24 & 3,33 & 3,20 \\
\hline 2. $\mathrm{N}_{12,5} \mathrm{P} 15 \mathrm{~K}_{15}$ & 3,45 & 3,48 & 3,58 & 3,40 \\
\hline 3. $\mathrm{N}_{25} \mathrm{P}_{30} \mathrm{~K}_{30}$ & 3,42 & 3,44 & 3,63 & 3,40 \\
\hline 4. residual effect NPK, manure & 3,51 & 3,42 & 3,54 & 3,30 \\
\hline 5.N 25 fertilization & 3,49 & 3,47 & 3,64 & 3,40 \\
\hline
\end{tabular}

The results of this table 4 reveal that the influence of studied manure dose is observed more clairly in the 'flowering' phase and formation of bud. Thereby, in the variant without improvement of manure of this in indicator is of 3,24 to $3,33 \mathrm{~g} / \mathrm{m}^{2}$ by leave the day. The use of minimal dose of manure $\left(\mathrm{N}_{12,5} \mathrm{P}_{15} \mathrm{~K}_{15}\right)$ thas increased the clean investment of photosynthesis seed at higher of 6,9 to $8,5 \%$. For all period of the germination until the formation of bud in the variant return this indicator has evolved of 3,0 to 5,9\%, the variant of accumulation signs absolutely of dry material of plants and the formation of leaves surface in certain interfacial periods of pea cultivation, has showed that, the investment of seeds by return to the unity of leaves in surface, depends in grant part of agro- meteorological of certainly cultivation years. Thereby, in 2016 year, when the fertility of grains of pea was minimal $(1,69-1,86 \mathrm{t} / \mathrm{ha})$, the greatest investment of the photosynthesis $\left(4,36-4,59 \mathrm{~g} / \mathrm{m}^{2}\right.$ by leave the day) has been establish to the biginning-germination-flowering ; and in 2018 - during the period of formation of buds- flowering $\left(4,13-4,85 \mathrm{~g} / \mathrm{m}^{2}\right.$ by leave the day).

In 2017, which defered the others by a grear investment $(4,09-4,69 \mathrm{t} / \mathrm{ha})$; in the most important period for the new harvesting ; period of formation of buds- a higher maturity ; when passed the formation and the growth of reproductive organ of plants, it has observed un higher investment of the photosynthesis of 4,46 to $4,93 \mathrm{~g} / \mathrm{m}^{2}$ leaf the day. It is necessary to underline that, during certains years of experiences conduct, they do not always observe a clean influence of manure dose of studied manure on this indicator.

\subsection{Discussion}

Experiences realised in the course of this study have permit to put in obviousness minimal dose manures mineral complet $\left(\mathrm{N}_{12,5} \mathrm{P}_{15} \mathrm{~K}_{15}\right)$ and the middle dose of mineral manures complet $\left(\mathrm{N}_{25} \mathrm{P}_{30} \mathrm{~K}_{30}\right)$ for determining the dynamic of accumulation of dry substance by the plants of variety (Local) of pea. Our result coincident with those of (Nondah, of 2004) which observed the greatest mass of dry material of plant during the period of complet maturity. Organic material under form of semi rot dung plays many rules in the improvement or the maintenance physics qualities of ground, in his capacity to store the reserves in water, in the development of microbic life ( Rouanet, 1986). For Dupriez and al (1983) recapture by swift and al, 1987. The manuring organic, such that animals bring the elements nutritive to the ground by improve his structure. The combinaison of residual effect, NPK manure permits thereby to obtain the good results middle dayly increase of substances at the beginning of cultivation (germination-formation of bud) on the plants (Geslin,1997). The dry material of stalks is form before the flowering, and in the reproductive period in the level of minimal doses complete minerals manure and the middle dose complete. It means that this period coincide with the delay of the flowering during which the thotosynthesis rate is arisen, in order to satisfy the needs of plant in elaborated necessary substances at the moment of floral initial (heller, 1995).

\section{CONCLUSION}

The manure influence positively the increase of accumulation of dry substance by the plants of pea. The good result are obtain by introducing completely mineral manure to the dose $\mathrm{N}_{25} \mathrm{P}_{30} \mathrm{~K}$ 30. it is establish confined bonds between the accumulation of dry substance and the return of pea $(r=0.839+0.172)$.

It is establish an considerably influence of manure on the photosynthetic potential of seeds and on the neat return of the photosynthesis pea. In all the doses of introduit manure. The photosynthetic potential of seeds increase and growth the return of photosynthesis.

The greatest return of pea seeds is constituate when the return maximal of the photosynthesis appearead during the most important period for the futur harvesting : formation of buds-full maturity. 


\section{REFERENCES}

- ABDOU D.B., 1987. Evaporation, transpiration and yield of four varieties of cowpea. Internship report, Faculty of Agronomy of Niamey Niger, $40 \mathrm{p}$.

- ANNONYME., 1989. Main enemies of cowpea and their control. Nigerian Plant Protection Project5.42p.

- ANNONYME., 2008. Operational Framework for the Implementation of the National Program for Food Security (NPFS) 2008-2009. Ministry of Agriculture and Livestock, Brazzaville Congo, 40 p

BALDY C., STIGTER C.J., 1993. Agrometeorology of multiple cultures in warm regons. Edition ENRA, Paris France. 246p.

- BORGET M., 1989. Tropical food legumes. Edition Maisonneuse and Larose, Paris, France, 162 p.

- BRASSANI R., 1997. Nutritive value of cowpea. In: cowpea reseach production and use. New York. 135-155p.

- DUPRIEZ and De LEENER P., 1983. Tropical agriculture in an African peasant environment. Earth and Life, The Harmattan, $280 \mathrm{p}$.

- GESLIN J.D., 1997.conservation and rehabilitation of soils. Africa Agriculture, No. 244p: 48-55.

- $\quad$ GEUT G., 1999. Memento of organic farming, 349p.

- KINZALI F., 2009. characterization of some varieties of vigna unguiculata (L) walp in the soil and climatic conditions of Nkouo. Master's thesis at the end of training for obtaining the diploma of Rural Development Engineer, Marien Ngouabi University, Institute of Rural Development (IDR), Brazzaville, Congo, 56 p.

- NITCHIPOROVITCH A.A., 1973.On the ways of increasing photosynthetic productivity of plants in crops // Photosynthesis and plant productivity issues //. M .: Edition To SC USSR, p. 5-36.

- NONDAH T., 2004. Contribution to the strategy of selection of genotypes of peppers (Capsicum annum, L) adapted to tropical conditions hot and humid. Master thesis for the Agronomy Engineer Diploma, National School of Agriculture, Senegal, Dakar, 71p

- QUIN F.M., 1997. Introduction advance in : cowpea reseach. Sayce publishing Devon U K. 9-15p.

- ROUANET G., 1986. Corn. The tropical agriculture technician. Editions Maisonneuse and Larose, 142p

- SING B.B., 1992. Selection of cowpea resistant to bruchs. I.I.T.A, number5 1-5pp

- SWIFTM.J. and LAVELLE P., 1987. Biological process and fertility of tropical soils. ProgRech.Coop. Proposed by the Union of Biological Sciences and MAB / UNESCO, 52p.

- TOTHILL J. 1986. The role of legums in forming of subs Saharan African in prociedind of a workshop help at ILCA, addid Abbeba Ethiopia. 16-19p. 